\title{
Um poeta em Vermelho
}

Adilson Citelli

Professor titular do Departamento de Comunicações e Artes da ECA/USP, onde ministra cursos de graduação e pós-graduação. Orienta dissertações e teses nas áreas de Comunicação e Linguagem, com ênfase nas subáreas Comunicação/Educação, Comunicação/Linguagem. É coeditor da revista Comunicação $\mathcal{E}$ Educação, bem como pesquisador $1 C$ do CNPQ*.

E-mail: citelli@uol.com.br

A seção Poesia tem procurado combinar a publicação de autores brasileiros e estrangeiros, alguns mais e outros menos conhecidos, no intuito de, ao mesmo tempo, fornecer referenciais canônicos e dar a nossos leitores jovens a oportunidade de conhecer poetas - ou, ao menos, aqueles cuja produção conhece circulação recente e mesmo mais restrita. Neste número, apresentamos alguns textos escritos por Agnaldo Gonçalves e saídos no livro Vermelho, publicado pela Editora Ateliê.

Agnaldo José Gonçalves nasceu em Buritama, estado de São Paulo, em 25 de agosto de 1949. É professor de Teoria Literária na Universidade Estadual Paulista Júlio de Mesquita Filho (UNESP), de São José do Rio Preto. Crítico literário refinado, autor de obras fundamentais para o estudo das traduções intersemióticas entre literatura e pintura, Agnaldo Gonçalves exercita em Vermelho uma série de jogos de linguagem que revelam procedimentos apropriativos, seja na vertente das artes plásticas, a exemplo dos diálogos com Miró, seja na da tradição poética encarnada em João Cabral de Melo Neto ou Paul Valéry. Arnaldo Antunes aponta, em seu prefácio, algumas das marcas presentes nos poemas de Vermelho:

Diversos procedimentos formais (verbovisuais, barrocoloquiais, poppontilhistas, impressimbolistas) se mesclam no mosaico vermelho de Aguinaldo - dos diálogos com a tradição que compõem sua parte $a$ (onde cada poema dedicado é um pouco impregnado pela forma daquele a quem se dedica), passando pelos grupos de poemas inter-relacionados por feixes de signos (parte $b$ ), que se rompem ("Óstraco") em estranhas justaposições de imagens mais distantes, surpreendentemente associadas (parte $c)^{1}$.

\section{IGNIÇÃO}
a João Cabral de Melo Neto as pedras as pedras as pedras! pétalas minerais deste lirismo crespas superfícies de amianto resistentes às chamas e ao inferno refratárias

fibras infernais deste tecido sedoso limbo em placas frias rebento controlado da miséria em pedras enjauladas

fricciono-as até o fogo e mais nada
*É autor de inúmeros
artigos e livros, dentre
os quais se destacam:
Linguagem e persuasão
(Ática, 1994); Comuni-
cação e Educação: a
linguagem em movimento
(Senac, 2000); Palavras,
meios de comunicação e
educação (Cortez, 2006).
1. Os indicadores a, b
e c, do prefácio escrito
por Arnaldo Antunes,
dizem respeito ao fato
de Vermelho estruturar-se
em três partes integra-
das. Em linhas gerais: na
primeira, há um diálogo
com poemas e poetas
lidos, num indicativo das
influências recebidas; na
segunda, existe um jogo
com imagens, indagando-
-se acerca da extensão
delas na e para a poesia;
e, na última, revelam-se
apreensões quase sensi-
tivas do que decorreu da
vivência do autor com as
manifestações artísticas. 
comunicação \& educação • Ano XVII • número 2 • jul/dez 2012

\section{ÓSTRACO}

meninos eu vi: pérolas rolando

pelas encostas de uma colina.

desfizeram-se do colar ao se arrebatar

contra um pequeno rochedo pérolas

soltaram-se do fio

$\mathrm{e}$

(soltas)

Saltitaram

como loucas:

pérolas

pérolas

pérolas

(completamente)

pérolas
redondas
postas
preciosas

buscando no desfiladeiro

seu ponto de origem.

a ostra (ou si mesma)

outra ostra

recanto nato e anatômico

glóbulo duro

brilhante e nacarado

formado na concha de moluscos bivalves

pérola pura

recomposta em adorno (como preciosa)

no pescoço do humano.

$$
\text { pérolas }
$$

pérolas

recônditas, redondas

ostreídeos

assim vivem

fixas nas pedras, ostramente

fixas nos ferros,

fixas na madeira, ostramente

fixas em si mesmas ostrasostras.

imunes ao Ostráceo (sempre ostra)

confundem-se no outro (Ostracismo).

como em outro sempre ostra (Ostracista)

pérolas recônditas pérolas nesse mover-se em busca

encontram nesta ostraria seu sinal de eternidade

$$
\text { e de repouso }
$$

serás sempre esse glóbulo ingênuo e precioso

desenho de uma forma

que se embate nesta geometria finda e infinda

como o glóbulo ocular

imune ao sol sem raios no nascente. 